New Zealand journal of industrial relations, 1988, 13, 295-299

\title{
A trade union perspective on sexual harassment
}

\author{
Martha Coleman ${ }^{*}$
}

Sexual harassment is a major workplace problem. It occurs in large workplaces and in small ones. Sexual harassment is no respector of race, age, class or status within the workplace or the community. Its victims are overwhelmingly women.

For the last decade at least, the Clerical Union has recognised the problem of sexual harassment. We have attempted to be supportive of members who have been harassed and in a wider context have taken political and industrial initiatives to get the problem of sexual harassment recognised, and to protect and compensate women for its effects.

The Clerical Union supported the inclusion of sexual harassment provisions within the Labour Relations Act. This was for three main reasons. Firstly, we believed it was important that sexual harassment be recognised as an industrial and workplace issue.

Secondly, we were concerned about the long delays often faced by complainants through the Human Rights procedure and hoped that the labour relations procedure would be faster. A quick resolution of a sexual harassment complaint is particularly important given the gruelling effects it has on most women.

Lastly, the Human Rights procedures do not allow for any third party referral. The exclusion of unions in favour of individual complainants in the Human Rights procedure does not enable us to properly support or be involved in the settlement of any claim. This put a lot more pressure on our members, and our deadlines after complaints were filed were usually at crisis times.

Aspects of the sexual harassment provisions that we see as being particularly beneficial are firstly the provisions relating to alternative procedures. We were pleased that recognition was given in the Act to the situation that many complainants may not wish to face their harasser within the context of a normal personal grievance hearing.

We were also pleased at the section relating to the question of evidence. We believed that this was a key provision in ensuring that the committee focuses on the offence and not on the victim. Under the old personal grievance procedures victims were placed in the position of having to justify their actions and themselves against innuendo, prejudice and lies.

In one case that I dealt with personally, the Employers Association presented evidence to the personal grievance committee that consisted of 20 interviews by the company. The interviewees were all asked what they "knew" about the victim, but not about the harasser, even though this man had harassed the two previous incumbents of the job, and was well known within the company to be a sexual harasser. Association 
The submissions from the Employers Association concluded that because she dressed "provocatively" and joined in the sexual banter in the office that no reasonable person could ever accept that she had been harassed. In that case I had no alternative but to recommend settling for a small amount of compensation. There was no way that I would suggest that the worker be subjected to more humiliation and personal attack by such allegations being made in open court.

Unfortunately, the special provisions for evidence do not apply when a victim is giving evidence in the case of a personal grievance brought by the alleged harasser. This is a major deficiency and should be altered.

There are other aspects of the provisions for sexual harassment that we would wish to see changed. We believe that the definition of sexual harassment is deficient in two important areas.

Firstly the definition did not encompass the concept of the display of pornographic pictures or of the existence of pornography in the workplace generally. At the 1984 Federation of Labour Conference our union put forward a remit that sought to extend the definition of sexual harassment to include "the display of pornographic pictures in the workplace, e.g. girly pinups, calendars etc. or other material which degrades women in particular". The remit was narrowly passed. Following the passing of that remit and the surrounding publicity, our union was inundated with calls from members who understood that pinups in the workplaces were now banned. They had mistakenly believed that the passing of a F.O.L. remit meant that they no longer had to be subjected to pinups in the workplaces.

Since 1984 there has been an explosion in the use of pornographic videos. These are being shown on employers video machines at social functions at lunchtimes and after work. This creates a climate of seeing women as sex objects, of women hating the degradation of women generally. It causes distress to women who sometimes have no alternative but to sit through these things or have lunch outside in the rain.

Our second major concern about the deficiencies of the provisions are those that relate to harassment by co-workers or clients of the employer. In such cases, these men can harass in many instances with impunity. There has been at least one instance relating to our members, where one of their male colleagues systematically and seriously harassed each one of them. A more common occurrence, is that after one experience of being harassed by a client or co-worker the woman is not able to continue in her employment, and leaves. Under the Act she is not entitled to any compensation for the loss for her employment.

How then have employers, mediators and the court handled sexual harassment cases? The simple response to that is badly. The Clerical Union has a number of concerns relating to recent sexual harassment cases that have proceded through personal grievances or Labour Court procedures. One such case related to a man who took a claim against his employer for unjustified dismissal. The background of this case is that one of our members made a complaint of sexual harassment to her company about the man in question. The company called in the harasser, told him of the allegation made against him, and dismissed him.

In a personal grievance hearing his dismissal was found to be unjustified on procedural grounds in that he was not given an opportunity to explain his actions. The mediator however stated in the decision that he had no doubt that the substance of the allegations were correct. Despite this, the mediator awarded the harasser $\$ 10,000$ for the loss of his employment.

Such an enormous sum in compensation by the mediator, led the harasser to the conclusion that he had been badly wronged over the incident of harassment. Buoyed up by this feeling he then proceeded to take a defamation case against our member. This resulted in our member having to employ legal counsel including a Queen's Counsel to defend her. As if this was not bad enough, the harasser appeared back on the worksite in the employ of an independent contractor. 
There are a number of similarities in that case to another one that was the subject of a Labour Court case. This one involved a butcher employed in a meat unit of a Woolworths Supermarket, and was taken by the butcher himself as he had been exempted from union membership. In this case the butcher was dismissed following a complaint of sexual harassment against him by a worker in the meat unit. It was not the first instance of harassment that had taken place and a previous complaint had led to the butcher being spoken to about his behaviour. In finding that the butcher had been unjustifiably dismissed the judge placed much importance on the manager's failure to properly investigate the complaint made. Also that the manager failed to take similar action against another butcher of whom complaints of sexual harassment had also been made. Reinstatement, compensation of $\$ 3,000$ and payment of lost wages were ordered. The company did not want the man to return to work. Instead, we understand, they offered and he accepted $\$ 50,000$ to resign.

Employers are making mistakes when dismissing people for sexual harassment. Employers who do not carry out dismissal procedures correctly in cases of sexual harassment further add to the burden of the victim who has already been harassed. This is completely inexcusable, and causes much additional suffering. This is particularly true when the harassers are awarded large amounts of compensation for a dismissal that is procedurally unfair only. In many instances workers who may have been dismissed unfairly on procedural grounds, but who have been held to have contributed to their dismissal by their actions, receive no compensation or very little compensation. Sexual harassers who are dismissed procedurally unfairly, seem to be awarded large and in some cases huge amounts of compensation.

Employers have to get their act together to stop the victims of sexual harassment from further disadvantage by incorrectly following dismissal procedures. Unions too must face up to the disciplinary procedures required for sexual harassment complaints. In most instances sexual harassment should be viewed as gross misconduct and the workers should be liable to instant dismissal. Unions and employers must both make it clear by their statements and their actions that sexual harassment is unacceptable. A clear message from Unions and employers about the unacceptability of sexual harassment will only work if that is backed up by mediators and the Labour Court. Unfortunately the two most recent decisions of the Labour Court relating to sexual harassment seem to indicate a lack of understanding about sexual harassment and the effects of sexual harassment on women.

In the butcher's case previously referred to, Chief Judge Horn seemed to denigrate the significance of complaints of sexual harassment, on the basis that there was some reluctance on the part of the complainants to come forward with their allegations. Rather than being unusual or suggesting that the harasser was not serious, this in fact is very normal in sexual harassment cases.

Victims are reluctant to speak out because they are embarrassed, because somehow they feel that perhaps they could have contributed to the problem, that they do not feel that their allegations will be taken seriously, that they feel that they should be able to cope with the harassment, or that they will be labelled as prudish or uptight because they find it offensive. I could go on, the reasons for reluctance to complain about sexual harassment are extensive. What must be acknowledged is that a reluctance in the first instance to complain in no way either lessens the seriousness of the harassment that has taken place or lessens the effect that harassment has had on the victim.

Further on in the judgement there is a discussion of one of the complainants. It says that she had developed a distrust of men generally and in the witness box displayed great animosity towards the butcher. This comment seems to fail to take into account the distrust and hostility that is generated as a result of being the victim of harassment. The judgement also discusses the stress in the worker's private life and again it seems to be suggesting that the worker is not in a position to judge what is harassment and what is not. I was somewhat appalled to read these comments as they seem to be barely a step removed from the "oh she does not have any sense of humour". 
Perhaps I am being sensitive on that point but certainly the evidence of the two women who made complaints about the man in question seemed to be given less weight than the two women witnesses called to support the harasser. It does, however, seem strange to me that the personal life of one complainant was mentioned in such a fashion that it implied that her judgement was impaired. It did not mention, however, that one of the women giving evidence in support of the alleged harasser was his girlfriend. Chief Judge Horn may be interested to note that after the decision was published in the paper, the Central Distribution Union received calls from people who had worked there previously. Even though no names or identifying facts were mentioned they had been able to pick who and where it was because his behaviour was not new.

To be fair, much blame must lie with the company in the way the case was handled. They told the union their support was not needed which in hindsight was a disastrous decision. This however emphasises again a very central point. When employers mess up the handling of a sexual harassment case they are not the only losers. Women are the ones who really suffer.

The next case I want to discuss involves a claim by a shop worker that she had been sexually harassed by a representative of her employer. She alleged that the manager had touched her breast, pinched her bottom, brushed his body against hers, called her names such as "baby" and "my love", and had put his arms around her, grabbed her from behind and had by means of a recited couplet asked her to have sexual intercourse with him. The court held that the actions and words alleged by the worker did occur, and that they constituted sexual harassment as defined by the Labour Relations Act.

They then went on to make in my view some astonishing comments. The judgement held that the sexual harassment, although significant, was not grave. The natural conclusion from that statement is that it is only women who have been raped who can claim to have been gravely harassed. This really belittles the sexual harassment that most women face.

The worker was awarded the sum of $\$ 1,500$ in compensation. Compare this to the $\$ 10,000$ paid to the harasser in the first case mentioned. The only conclusion that can be drawn in such a comparison, is that the loss of a man's employment as a result of some procedural unfairness in dismissal, is more important than compensating a woman for harassment. Such a conclusion is obviously unacceptable and denotes a total lack of understanding of the effects of sexual harassment on women.

In the case of the shop worker, she left her job on the advice of a union official. In discussing that, Judge Finnigan made two quite extraordinary comments. He said, "we would not like to encourage a view that an allegation by a worker of sexual harassment is sufficient ground for abandonment of employment. It may be so in some cases but not in our view in the present case."

I cannot accept this. Sexual harassment must always be grounds for constructive dismissal. Very, very few women are able to continue working with the ease and comfort to which they are entitled alongside or subordinate to their harasser. Whether or not you are able to remain happily employed is a very individual decision and should in no way detract from the general applicability of a constructive dismissal remedy.

Judge Finnigan also said in referring to the union official's advice to the worker to leave her job that "it necessarily destroyed the relationship of employer and worker which was important to the worker and which she herself did not intend to destroy."

With due respect to Judge Finnigan, to suggest that the relationship of employer to worker had not already been destroyed by the sexual harassment that took place seems quite absurd.

After the case involving our member where the harasser was awarded a large sum of compensation, the Clerical Union approached the Chief Mediator to discuss our concerns about the handling of sexual harassment cases. Amongst our requests was one that all mediators be educated about sexual harassment and its effects. Specifically we suggest that mediators receive training from the Human Rights Commission and Rape Crisis and 
Women's Refuge workers. This has not happened. The decisions of the Labour Court on sexual harassment lead me to the conclusion that those bodies too need to be trained on the same issue.

The Clerical Union fought hard for the inclusion of special sexual harassment procedures to be included in our awards and for sexual harassment to be included in the Labour Relations Act. Changing procedures though is not enough. The attitudes of employers, mediators, the Labour Court and some trade unions who defend harassers, must change too.

In order for women to be better protected in the future we call for the following changes to be made:

1. An extension of the evidence provisions relating to sexual harassment to other personal grievance cases if they are related to a sexual harassment complaint.

2. An extension of the definition of sexual harassment to cover pornography.

3. A recognition by trade unions that in most instances sexual harassment will be "gross misconduct".

4. Special training for all people who make decisions in sexual harassment or related cases and the appointment of a specialist mediator expert in gender discrimination.

5. A special right for a victim of harassment to seek compensation from the employer as a result of her employer's mishandling of a complaint that causes her further distress.

This is just a start, but it is a necessary beginning if we are serious about dealing with sexual harassment and its effects. 